\title{
Effect Of Labour Flexibility On Productivity In The Andalusian Hotel Industry
}

Alejandro García-Pozo, University of Malaga, Spain

Andrés Marchante-Mera, University of Malaga, Spain

José Luis Sánchez-Ollero, University of Malaga, Spain

\begin{abstract}
The authors analyze the effect of labour flexibility on productivity in the Andalusian hotel industry. For this purpose, the authors use the results from the Quality, Productivity and Competitiveness in the Hospitality Industry for Andalusia project (PO7/SEJ-02889). The model used considers three employment shares - open-ended contracts, temporary contracts, and parttime contracts. However, it should be borne in mind that the Spanish model of labour flexibility has mainly focused on the use of temporary contracts rather than other human resource management practices, such as internal labour flexibility.
\end{abstract}

Keywords: Labour Flexibility, Productivity, Hospitality

\section{INTRODUCTION}

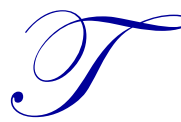

emporary contracts would have positive effects on the Spanish economy, where permanent workers have high levels of employment protection (Ortega and Marchante, 2010). This type of contract may provide a way for improving labour market flexibility, since firms can adjust their workforces by varying the number of temporary workers (Booth et al., 2002) and could also provide the firm with new workers who are employed for a specific probation period in order to test whether they are suitable for an open-ended job. This type of employment can have a positive impact on the firm's performance if temporary workers perceive that the probability of rehiring depends on their aptitude and work effort. Moreover, temporary contracts may provide the firm with workers who replace staff on leave due to maternity, sickness, and so on.

These contracts may also encourage entrepreneurship and business start-up by reducing the fixed costs of recruitment, training, and redundancy by using agencies (Green, 2008). In this sense, it is accepted that temporary contracts, whose main distinguishing feature is that they reduce labour costs compared to other types of contract, have led to the creation of jobs, mainly in those economic sectors in which productivity is lower and there is high employee turnover. However, it is also noteworthy that the use of temporary contracts has had a negative impact on both job security and incentives to accumulate human capital and, consequently, on increasing productivity.

In addition, there doesn't seem to be a direct relationship between productivity and employee turnover. When labour turnover is low, productivity will also be low because the efficient reallocation of the productive factor would occur more slowly from jobs with lower productivity to those with higher productivity. Conversely, if labour turnover is very high, it would discourage both workers and employers to invest in training, thus making the accumulation of human capital more difficult. Therefore, temporary contracts would have marked effects on worker productivity due to their impact on job turnover.

Theoretical predictions are ambiguous regarding the expected effects of part-time work on firm productivity (Nelen et al., 2009). Human capital theory suggests that there is a negative relationship between parttime employment and labour productivity. The reason behind this is the low incentive for part-time workers to invest in human capital, which leads to these workers under-performing in terms of productivity compared to full-time workers (Manning and Petrongolo, 2008). Secondly, hiring part-time workers could be beneficial to the productivity of the company in the event that the hours worked by these employees are more than those established in their contracts or when consumer demand is concentrated in specific certain peak hours (Delsen, 2006; Rosendaal, 2003). 


\section{THEORETICAL MODEL}

The authors extend the standard production function by distinguishing between part-time, temporary, and full-time labour inputs and they follow Nelen et al. (2009) and Ilmakunnas and Maliranta (2005) in the way they model the productivity effects of different employment shares. This so-called share-approach to including heterogeneous labour inputs assumes that different types of employees are perfect substitutes, but may have different marginal productivities. The workforce is divided into three employment shares - part-time (PT), full-time permanent (FT), and temporary employees (TE). Taking the full-time permanent contracts as a reference group and scaling its productivity to one, the relative productivity of the part-time employment share equals $\Upsilon_{\mathrm{pt}}{ }^{-1}$ and the relative productivity of the temporary employment share equals $\left(\Upsilon_{\mathrm{te}}-1\right)$. The quality-adjusted labour input is therefore:

$L^{*}=\mathrm{L}[1+(' \Upsilon \mathrm{pt}-1) \mathrm{PT}+($ 'Yte-1)TE $]$

Equation 1 can be simplified using the following expression:

Ln [1+('Ypt-1)PT+('Yte-1)TE] <>('Ypt-1)PT+ ('Yte-1)TE

The part-time and temporary employment shares are thereby directly included in a log-form production function. Using the quality-adjusted labour input $\left(L^{*}\right)$, the production function is written as follows:

$\mathrm{Y}=\mathrm{AK}^{\alpha} \mathrm{L}^{* \beta}$

or in logs and using the expression in equation (2):

$\ln (\mathrm{Y})=\phi+\alpha \ln (\mathrm{K})+\beta \ln (\mathrm{L})+{ }^{\prime} \Upsilon^{*} \mathrm{ptPT}+{ }^{\prime} \Upsilon * \operatorname{teTE}$

where $\phi=\ln (\mathrm{A}) ;{ }^{\prime} \Upsilon^{*}{ }_{\mathrm{pt}} \mathrm{PT}=\beta\left({ }^{\prime} \Upsilon_{\mathrm{pt}}-1\right)$ and ${ }^{\prime} \Upsilon^{*}{ }_{\mathrm{te}}=\beta\left({ }^{\prime} \Upsilon_{\mathrm{te}}-1\right)$

\section{DATABASE}

The database was created as part of the Quality, Productivity and Competitiveness in the Hospitality Industry for Andalusia project (PO7/SEJ-02889). It includes representative parameters from 232 Andalusian hotels (96 rated as 3-star, 126 as 4-star, and 10 as 5-star) offering a total of 64,036 beds, representing $34.99 \%$ of the total beds offered by these types of establishments in Andalusia at the end of 2009. These parameters were obtained from semi-structured questionnaires administered to the hotel managers by the researchers. According to SIMA (the Multiterritorial Information System of Andalusia), which was created by the Institute of Statistics and Cartography of Andalusia, there were a total of 822 establishments in these categories in Andalusia in 2009, and thus the database provides direct information on $28.2 \%$ of all hotels in the region. Given that Andalusia is very large, the authors took the distribution of the sample into account, bearing in mind the relative importance of the hotel sector in each province. In addition, they included control variables to identify establishments according to their location (coastal, inland, or capital city) and other control variables that reflect the establishments' structural and management characteristics.

The fieldwork for the study was conducted in person by researchers from the universities of Malaga, Granada, and Seville in 2010. The economic data were obtained directly via questionnaires and the annual accounts filed by firms in the Mercantile Registry.

A directory of the hotels to be surveyed was created using the Turespaña Hotel Guide which lists certified hotels published by the local government of Andalusia (i.e., the Junta de Andalucía) and Camerdata. After discarding the questionnaires that had not been correctly completed, the final sample consisted of 181 hotels. 


\section{CONCLUSIONS}

The results indicate that productivity in Andalusian hotels is lower the higher the percentage of temporary and part-time workers. Furthermore, there are no statistically significant differences between the negative impacts on productivity of both types of labour contract. However, since the costs associated with both temporary and parttime workers are lower than those of workers with full-time permanent contracts, future studies should analyze the differential impact of all the types of contracts discussed on the mean cost per employee in hotels.

\section{AUTHOR INFORMATION}

Alejandro García-Pozo has a Ph.D. and a Degree in Economics \& Business Studies at University of Malaga and is a Senior Lecturer in Economics at University of Malaga, Faculty of Economics \& Business Studies, Department of Applied Economics at University of Malaga (Spain). Research Interests include Labor market, productivity and wages, returns on human capital, and sustainable development in tourism sector. E-mail: alegarcia@uma.es

Andrés Marchante-Mera has a Ph.D. and Degree in Economics \& Business Studies at University of Malaga and is a Professor in Economics at University of Malaga, Faculty of Economics \& Business Studies, Department of Applied Economics at University of Malaga (Spain). Research Interests include Productivity analysis and labor supply. E-mail: marchante@uma.es

José Luis Sánchez-Ollero has a Ph.D. and Degree in Economics \& Business Studies at University of Malaga andis a Senior Lecturer in Economics at University of Malaga, Faculty of Economics \& Business Studies, Department of Applied Economics at University of Malaga (Spain). Research Interests include Labor market, productivity and wages, returns on human capital, and sustainable development in tourism sector. E-mail: jlsanchez@uma.es (Corresponding author)

\section{REFERENCES}

1. Booth, A.L., Dolado, J.J. and Frank, J. (2002): "Symposium on temporary work. Introduction", The Economic Journal, 112(480), F181-F188.

2. Delsen, L. E. (2006): Operating hours and working time: a survey of capacity utilization and employment in the European Union, Springer Press, New York.

3. Dolado, J.J., García-Serrano, C. and Jimeno, J.F. (2002): "Drawing lesson from the boom of temporary jobs in Spain", The Economic Journal, 112(480), F270-F295.

4. Green, F. (2008): “Temporary work and insecurity in Britain: a problem solved?", Social Indicators Research, 88, 147-160.

5. Ilmakunnas, P. and Maliranta, M. (2005): “Technology, Labour Characteristics and Wage-productivity Gaps", Oxford Bulletin of Economics and Statistics, 67(5), 623-645.

6. Manning, A. and Petrongolo, B. (2008): "The part-time pay penalty for women in Britain", The Economic Journal, 118(526), F28-F51.

7. Nelen, A., De Grip, A., and Fourage, D. (2009): "Does part-time employment affect firm productivity", Occasional Paper Series, Research Centre for Education and the Labor Market, Maastricht University, The Netherlands.

8. Ortega, B. and Marchante, A.J. (2010): “Temporary contracts and labour productivity in Spain: a sectoral analysis", Journal of Productivity Analysis, 34, 199-212.

9. $\quad$ Rosendaal, B. (2003): "Dealing with Part-time Work", Personnel Review, 32(4), 474-491. 
NOTES 